\title{
Analysis of steel frames strenghtened with diagonally installed mechanical dampers
}

\author{
Emir Buljubašić, M.Eng.C.E. \\ emir.buljubasic1@gmail.com \\ Goran Simonović \\ University of Sarajevo, Faculty of Civil Engineering, Ph.D C.E. \\ goran.simonovic@gf.unsa.ba
}

\begin{abstract}
This paper is a continuation of the research on reinforcement of masonry walls using a combination of metal frames and mechanical dampers. This paper analyzes a single metal frame with and without reinforcement with mechanical dampers in order to have a clearer insight into the behavior of individual reinforcement components. It presents an overview of the basic characteristics of mechanical dampers, their configuration and combinations with metal frame, and special emphasis is placed on their earthquake behavior. The results of the numerical analysis for a single metal frame were obtained using two modern software packages, ABAQUS and SAP2000. After the results of the individual metal frame were obtained, the metal frame was strengthened by applying mechanical dampers and analyzed.
\end{abstract}

Key words: metal frame, earthquake, seismic action, strengthening of metal frames, mechanical dampers, passive dampers, energy dissipation devices, seismic isolation, numerical analysis of metal frames, pushover analysis, dynamic analysis, cyclic loading of metal frames

\section{Analiza ojačanja metalnih okvira s dijagonalno instaliranim mehaničkim damperima}

Sažetak: Ovaj rad predstavlja nastavak istraživanja na ojačanju zidanih zidova uporabom kombinacije metalnih okvira i mehaničkih dampera. $U$ ovom radu izvršena je analiza samostalnog metalnog okvira sa i bez ojačanja mehaničkim damperima kako bi imali jasniji uvid u ponašanje pojedinačnih komponenti ojačanja. Prikazan je pregled osnovnih karakteristika mehaničkih dampera, njihove konfiguracije i kombinacije sa metalnim okvirom, te je poseban naglasak stavljen na njihovo ponašanje uslijed zemljotresa. Rezultati numeričke analize za pojedinačni metalni okvir dobiveni su upotrebom dva suvremena programska paketa, ABAQUS-a i SAP2000-a. Nakon dobivenih rezultata pojedinačnog metalnog okvira, izvršeno je ojačanje metalnog okvira apliciranjem mehaničkih dampera te izvršena njihova analiza.

Ključne riječi: metalni okvir, zemljotres, seizmičko djelovanje, ojačanje metalnih okvira, mehanički damperi, pasivni damperi, uređaji za disipaciju energije, seizmička izolacija, numerička analiza metalnih okvira, pushover analiza, dinamička analiza, ciklično opterećenje metalnih okvira 
Buljubašić, E., Simonović, G.

Analysis of steel frames strenghtened with diagonally installed mechanical dampers

\section{INTRODUCTION}

This paper is a continuation of the research on reinforcement of masonry walls using metal frames reinforced with mechanical dampers [1]. Previous analysis has shown that walls are quite rigid structural elements, without pronounced ductility, which makes questionable their coupling with dampers which are markedly ductile, because failure occurred in the wall before activation of dampers.

In order to have a clearer insight into the behavior of individual reinforcement components, in this paper we conducted a numerical analysis of a single metal frame loaded under the same conditions as the masonry walls tested in the laboratory of the Institute for Materials and Structures of the Faculty of Civil Engineering in Sarajevo [2, 3, 4, 5, 6].

It should be emphasized that dampers are used in different fields of construction where seismic resistance of structures should be improved. Using mechanical dampers can help improve the dynamic characteristics of structures during an earthquake by modifying the characteristics of structural response. The primary reason for using energy dissipation devices in structures is to reduce the displacement and damage caused by excessive structural deformation. The displacement reduction is achieved by adding stiffness and/or energy dissipation (damping) to the structure of a building or an individual structural element [7].

After the results of numerical analysis of the metal frame were obtained, mechanical dampers were diagonally applied and the effects of their application were examined.

\section{MATERIAL AND GEOMETRIC CHARACTERISTICS OF METAL FRAME}

The dimensions of the metal frame for the purposes of numerical analysis were selected based on the dimensions of reduced masonry walls $(\mathrm{l} / \mathrm{h} / \mathrm{w}=103 / 103 / 25 \mathrm{~cm})$ which were tested in the laboratory of the Institute for Materials and Structures of the Faculty of Civil Engineering Sarajevo in Sarajevo [2, 3, 4, 5, 6].

The necessary values of the axial pressure and tension forces in the frame columns for dimensioning are obtained based on known geometric and material characteristics of the wall and the metal frame, as well as the precompression level of the wall. These values were obtained from the masonry wall equilibrium conditions, taking into account that the material is linearly elastic because due to the large axial load, the used equilibrium equations would not be applicable for the wall to go to a nonlinear state.

To model the metal frame, we used class S235 steel with the liquid limit of $f_{y}=235 \mathrm{~N} / \mathrm{mm}^{2}$, the dimensions of the frame are $\mathrm{h} / \mathrm{l}=103 / 103 \mathrm{~cm}$. Hollow sections HOP $60 \times 60 \times 4$ were used for beams and columns.

\section{MECHANICAL DAMPERS (SEISMIC DAMPERS) - PASSIVE ENERGY DISSIPATION SYSTEMS}

Using mechanical dampers can help improve the dynamic properties of structures during an earthquake by modifying the characteristics of structural response. By using passive energy dissipator systems, we can achieve a response reduction of two to three times if they do not add stiffness and more than that in the case of additional stiffness [7].

Passive energy dissipation systems add damping (sometimes also stiffness) to the building, and thus reduce structural response to seismic actions. These systems reduce forces in the structure while it operates in the elastic range. The primary reason for using 
Buljubašić, E., Simonović, G.

Analysis of steel frames strenghtened with diagonally installed mechanical dampers

energy dissipation devices in structures is to reduce the displacements and damage caused by excessive structural deformation. The displacement reduction is achieved by adding stiffness and/or energy dissipation (damping) to the building structure [7].

Energy dissipation devices based on metal flow, friction, and viscoelastic damping add both stiffness and damping to the structure, while viscous dampers generally only increase damping in the frame structure of the building. We will focus on the first group of dampers that contributes to increasing the stiffness of the structure. Figure 1 shows the hysteretic behavior and physical models of individual types of mechanical dampers.

\begin{tabular}{|c|c|c|c|c|}
\hline & Viscous damper & $\begin{array}{l}\text { Viscoelastic } \\
\text { damper }\end{array}$ & $\begin{array}{c}\text { Hysteretic metal } \\
\text { damper }\end{array}$ & $\begin{array}{c}\text { Friction-based } \\
\text { hysteretic damper }\end{array}$ \\
\hline $\begin{array}{c}\text { Basic } \\
\text { structure }\end{array}$ & 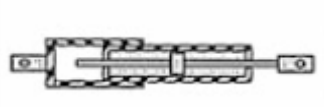 & जा & of & a \\
\hline $\begin{array}{l}\text { Idealized } \\
\text { hysteretic } \\
\text { behavior }\end{array}$ & Displacement & Displacement & Displacement & Displacement \\
\hline $\begin{array}{c}\text { Idealized } \\
\text { physical } \\
\text { model }\end{array}$ & $\bigotimes_{\text {Displacement }}^{\longrightarrow} \underset{\mathrm{L}}{\stackrel{\text { Force }}{\longrightarrow}}$ & $\underset{\text { Displacement }}{\stackrel{\text { Force }}{\longrightarrow}}$ & $\begin{array}{l}\text { Idealized } \\
\text { model is not } \\
\text { available }\end{array}$ & $\underset{\text { Displacement }}{\stackrel{\text { Force }}{\longrightarrow}}$ \\
\hline
\end{tabular}

Figure 1. Idealized hysteretic behavior and physical models of dampers [8]

\subsection{Selection of mechanical dampers for strengthening purposes and their configuration}

It should be emphasized that the improvement of seismic resistance by using mechanical dampers is essentially reduced to vibration damping, but their installation also increases the stiffness of the element being strengthened. So, the focus of this paper will be more oriented towards the effects of increasing stiffness due to the strengthening of the element by mechanical dampers.

There are different ways of installing dampers in a structure. The configuration of dampers is their positioning during installation. Figure 2 shows some of the most common damper installation methods.

Mechanical dampers are usually installed so as to be an integral part of other elements, usually metal sections in some of the specified ways (Figure 2). This is due to the relatively small dimensions of the damper in relation to the element being strengthened, which however depends on the type of damper and the degree of load.

In this paper, only simple diagonal reinforcement will be used (Figure 2a). Due to the seismic action, the resultant of the vertical pressure and transverse load forces resulting from the earthquake will be transferred diagonally through the wall. Due to the low tensile strength 
Buljubašić, E., Simonović, G.

Analysis of steel frames strenghtened with diagonally installed mechanical dampers

of the masonry, tension will occur perpendicular to the formed pressed diagonal, which will cause hinges to separate and bricks to fail. The idea is to take a part of the tensile force with the mechanical damper and reduce its effect on the masonry wall, i.e. to transfer it to the added metal frame.

During seismic activities, the structure works so that the damper, if not well stiffened, will also be displaced out of its original axis. If it is an integral part of other elements (metal sections) that can locally bend, then its effectiveness can be reduced if sections that are more resistant to this effect are not selected (Figure 3).

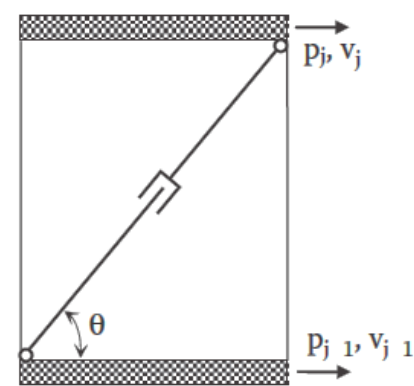

(a)

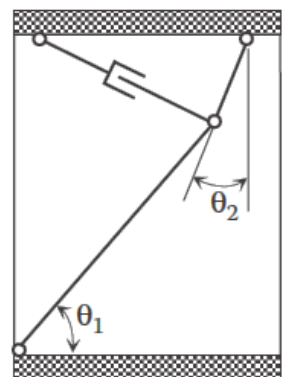

(d)

(e)

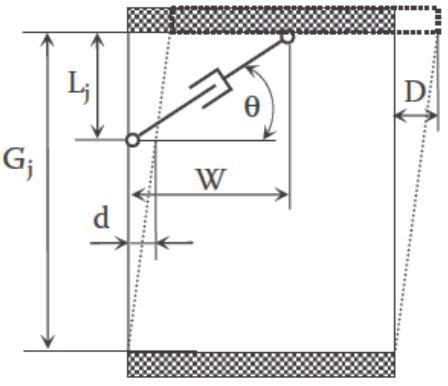

(b)

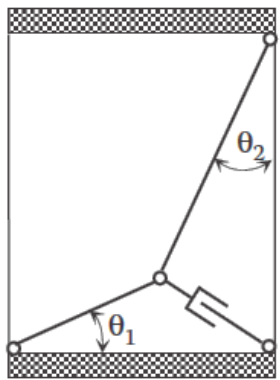

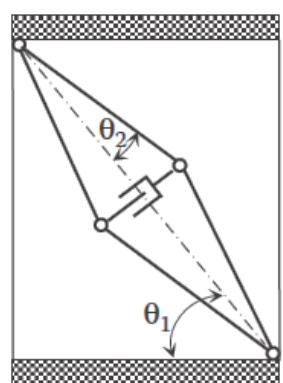

(f)

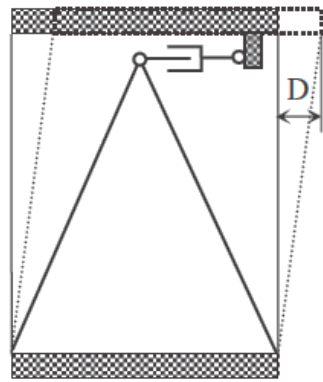

(c)

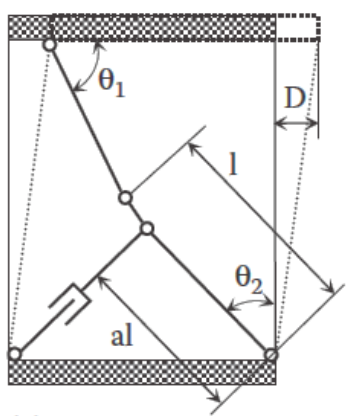

(g)

Figure 2. Some examples of damper installation [9]

(a)

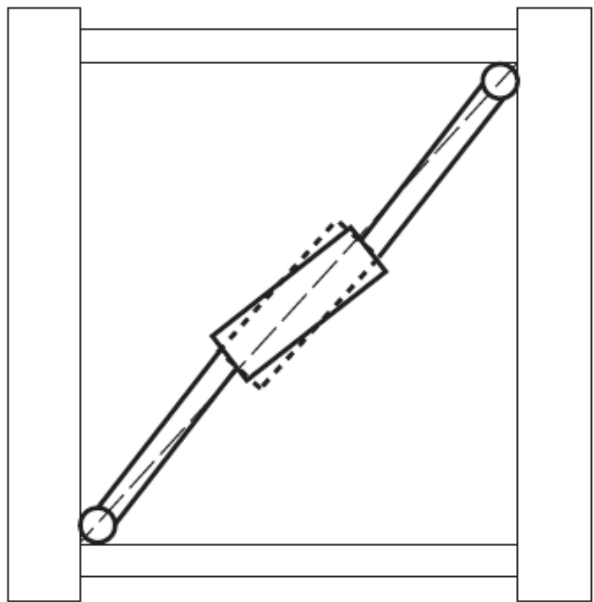

(b)

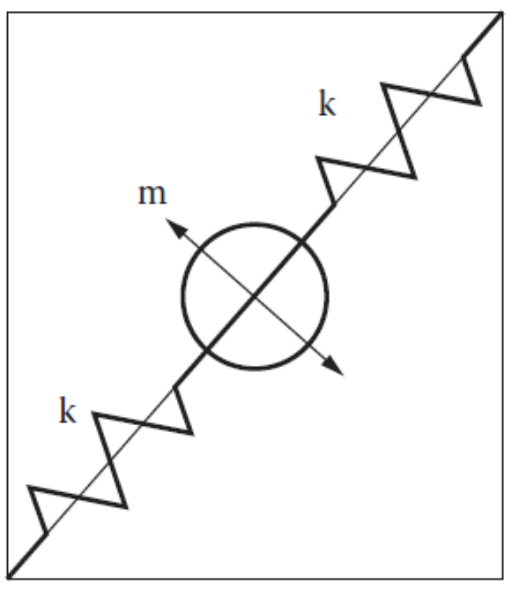

Figure 3. Damper displacement due to lateral load [9] 
Buljubašić, E., Simonović, G.

Analysis of steel frames strenghtened with diagonally installed mechanical dampers

In order to avoid this error, but also to be able to cover various types of mechanical dampers with a single model, a simplification by replacing the damper with a spring with a defined stiffness will be made below (Figure 4). Depending on the type of damper, the manufacturer defines the ultimate forces and displacements that the damper can take as well as its degree of damping, so regardless of the degree of damping, the damper will certainly contribute to increasing the stiffness of the element being reinforced.

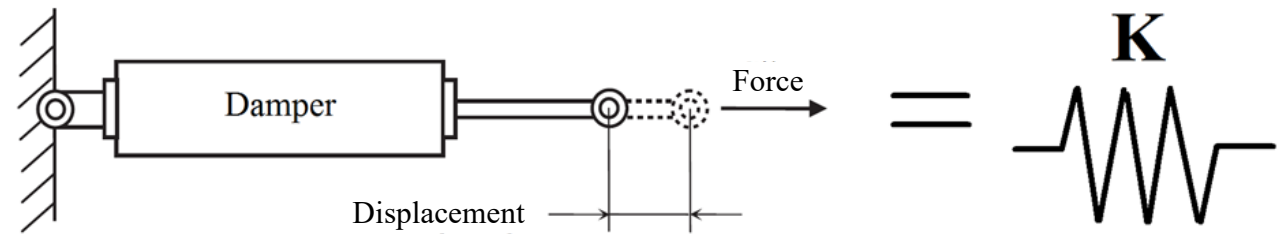

Figure 4. Mechanical damper and the used damper replacement model

\section{NUMERICAL MODELING OF METAL FRAMES REINFORCED WITH MECHANICAL DAMPERS}

\subsection{Modeling of metal frame}

When modeling the metal frame, we used class $S 235$ steel with the liquid limit of $f_{y}=235$ $\mathrm{N} / \mathrm{mm}^{2}$, the dimensions of the frame are $\mathrm{h} / \mathrm{l}=103 / 103 \mathrm{~cm}$. Hollow sections HOP $60 \times 60 \times 4$ were used for beams and columns. Since the wall that needs to be strengthened with a metal frame was previously subjected to a vertical pressure of $\sigma_{o}=0.4 \mathrm{~N} / \mathrm{mm}^{2}$, the same load was applied to the metal frame. The frame columns are fixed to the bottom while the frame beam is allowed to move in its plane.

\subsubsection{Modeling of metal frame using the SAP2000 software package}

To model the metal frame, we used class S235 steel with the characteristics shown in Figure 5. The dimensions of the frame are $h / l=103 / 103 \mathrm{~cm}$. Hollow sections HOP $60 \times 60 \times 4$ were used for beams and columns. For their modeling, we used frame elements, increasing in the process the axial stiffness of the frame beam in order to simulate more realistic conditions, because it is planned to fix the frame beam to the ceiling for better transfer of impacts to the frame columns. 
Buljubašić, E., Simonović, G.

Analysis of steel frames strenghtened with diagonally installed mechanical dampers

\begin{tabular}{|c|c|c|c|}
\hline \multicolumn{2}{|l|}{ Weight and Mass } & \multicolumn{2}{|l|}{ Units } \\
\hline Weight per Unit Volume & 76,9729 & $\mathrm{KN}, \mathrm{m}, \mathrm{C}$ & $\checkmark$ \\
\hline Mass per Unit Volume & 7,849 & & \\
\hline \multicolumn{4}{|l|}{ Isotropic Property Data } \\
\hline \multicolumn{2}{|l|}{ Modulus of Elasticity, $\mathrm{E}$} & $2,100 E+08$ & \\
\hline \multicolumn{2}{|l|}{ Poisson, U } & 0,3 & \\
\hline \multicolumn{2}{|c|}{ Coefficient of Thermal Expansion, A } & $1,170 \mathrm{E}-05$ & \\
\hline \multicolumn{2}{|l|}{ Shear Modulus, G } & 80769231 & \\
\hline \multicolumn{4}{|c|}{ Other Properties for Steel Materials } \\
\hline \multicolumn{2}{|c|}{ Minimum Yield Stress, Fy } & 235000, & \\
\hline \multicolumn{2}{|c|}{ Minimum Tensile Stress, Fu } & 360000, & \\
\hline \multicolumn{2}{|c|}{ Effective Yield Stress, Fye } & 258500, & \\
\hline \multicolumn{2}{|c|}{ Effective Tensile Stress, Fue } & 396000 & \\
\hline
\end{tabular}

Figure 5. Mechanical characteristics of selected steel - SAP2000

After forming a numerical model of the metal frame (Figure 6) for the purposes of pushover analysis, it is necessary first to define plastic hinges in order to take into account the possible plasticization of column bases due to seismic action. SAP2000 has standard, predefined hinges, so it is not necessary to specify new ones. More precisely, there are two basic types of hinges: standard hinges and hinges defined by the designer as well as generated hinges, however only the first two types can be associated with frame elements [10]. Members were selected and Hinge options were assigned by default for the combination of axial force and bending moment P-M3 (Figure 7).
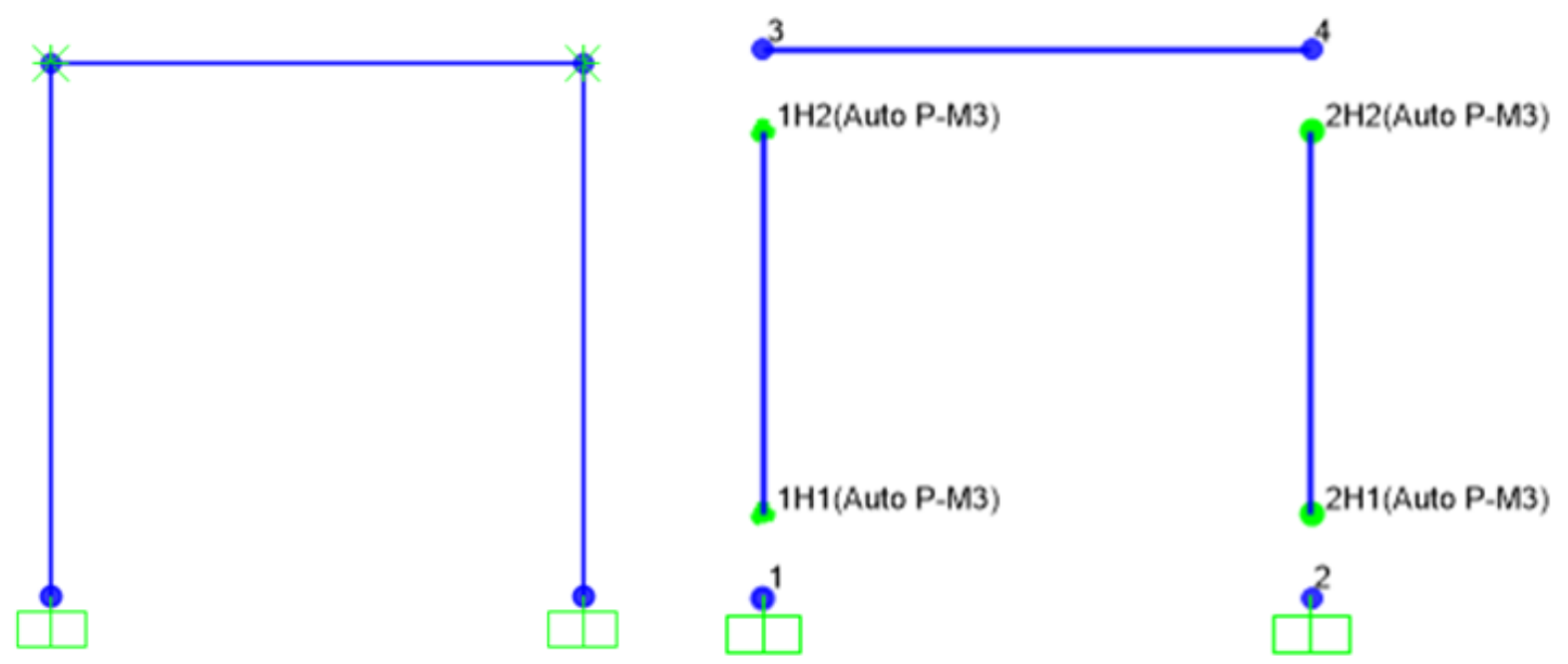

Figure 6. Numerical model of metal frame and set plastic hinges - SAP2000 
Buljubašić, E., Simonović, G.

Analysis of steel frames strenghtened with diagonally installed mechanical dampers

\begin{tabular}{|c|c|c|c|c|}
\hline \multicolumn{5}{|l|}{ Auto Hinge Type } \\
\hline \multicolumn{4}{|c|}{ From Tables In FEMA 356} & $\checkmark$ \\
\hline \multicolumn{5}{|c|}{ Select a FEMA356 Table } \\
\hline \multicolumn{3}{|c|}{ Table 5-6 (Steel Columns - Flexure) } & & $\checkmark$ \\
\hline Component Type & \multicolumn{2}{|c|}{ Degree of Freedom } & Deformation Controlled Hinge Load Carrying Capacity & \\
\hline (-) Primary & $\mathrm{M} 2$ & P-M2 & (-) Drops Load After Point E & \\
\hline \multirow[t]{2}{*}{ Secondary } & $\bigcirc m 3$ & (c) P-M3 & $O$ is Extrapolated After Point E & \\
\hline & M2-M3 & P-M2-M3 & & \\
\hline
\end{tabular}

Figure 7. Selected type of plastic hinges P-M3

Properties of the assigned plastic hinges P-M3 are shown in Figure 8. When assigning the plastic hinges to metal columns, care was taken to position them at the ends of the columns. We placed them where we expect plasticization of the cross-section by entering the ends of the members with numbers 0 and 1 at Relative Distance positions in the "Frame Hinge Assignment Data" window (Figure 8). The numerical model of the metal frame and the plastic hinges assigned to the frame columns are shown in Figure 6, while the types of assigned plastic hinges are shown in Figure 9.

Moment Rotation Data for Selected Curve

\begin{tabular}{|c|c|c|}
\hline Point & Moment/rield Mom & Rotation/SF \\
\hline A & 0, & 0, \\
\hline B & 1, & 0, \\
\hline C & 1,25 & 6, \\
\hline D & 0,2 & 6, \\
\hline E & 0,2 & 8, \\
\hline
\end{tabular}

Copy Curve Data Paste Curve Data

Acceptance Criteria (Plastic Deformation / SF)

Immediate Occupancy

Life Safety

Collapse Prevention

Show Acceptance Points on Current Curve

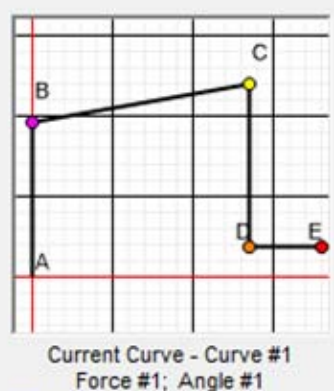
30 View

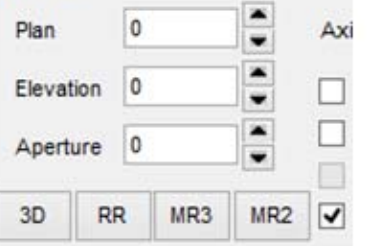

Figure 8. Properties of the selected P-M3 plastic hinges 
Buljubašić, E., Simonović, G.

Analysis of steel frames strenghtened with diagonally installed mechanical dampers

All Hinge Props
\begin{tabular}{|c|c|c|c|c|}
\hline Name & Type & Behavior & Generated & From \\
\hline $2 \mathrm{H} 1$ & Interacting P-M3 & Deformation Controlled & Yes & Auto \\
\hline $2 \mathrm{H} 2$ & Interacting P-M3 & Deformation Controlled & Yes & Auto \\
\hline $3 \mathrm{H} 1$ & Interacting P-M3 & Deformation Controlled & Yes & Auto \\
\hline $3 \mathrm{H} 2$ & Interacting P-M3 & Deformation Controlled & Yes & Auto \\
\hline
\end{tabular}

Figure 9. Types of plastic hinges assigned to the frame columns

\subsubsection{Modeling of metal frame using the ABAQUS software package}

Metal frames were modeled using two-node linear beam finite elements in space B31. The global size of the finite elements is $50 \mathrm{~mm}$. Material characteristics of numerical models as well as the description of finite elements are given in Table 1.

The steel beam of the frame will be anchored to the ceiling; in order to take this effect into account, we increased the axial stiffness of the beam. Plasticization of the column bases was taken into account in the ABAQUS software package, so that it was not necessary to further define them. After the metal frame was tested without strengthening, a diagonal mechanical damper was added to it using connector elements (Figure 10).
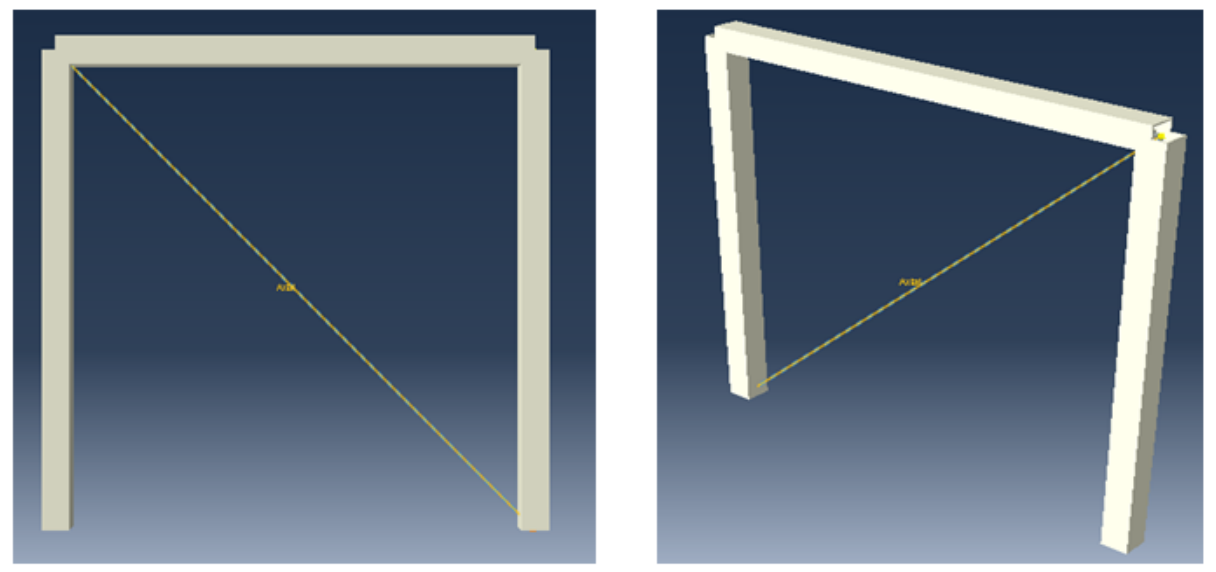

Figure 10. Numerical model of metal frame - ABAQUS

\subsection{Modeling of metal frame strengthened with mechanical damper}

A mechanical damper was applied diagonally to the metal frame with the properties specified below. The numerical model and formation of plastic hinges during pushover analysis are shown in Figure 11. 
Buljubašić, E., Simonović, G.

Analysis of steel frames strenghtened with diagonally installed mechanical dampers

Table 1. Material characteristics of numerical models and description of finite elements ABAQUS

\begin{tabular}{|c|c|c|c|}
\hline \multicolumn{2}{|c|}{ Elements } & Metal frame & Mechanical damper \\
\hline \multicolumn{2}{|c|}{$\begin{array}{l}\text { Bulk density } \\
{\left[\text { Tonnes } / \mathrm{mm}^{3} \text { ] }\right.}\end{array}$} & 7.70E-09 & - \\
\hline \multicolumn{2}{|c|}{$\begin{array}{l}\text { Modulus of elasticity } \\
\qquad\left[\mathrm{N} / \mathrm{mm}^{2}\right]\end{array}$} & 210000 & - \\
\hline \multicolumn{2}{|c|}{ Poisson's ratio } & 0.25 & - \\
\hline \multicolumn{2}{|c|}{ Type of element } & $\begin{array}{l}\text { B31: linear beam finite element } \\
\text { with two nodes in space }\end{array}$ & Connector \\
\hline \multicolumn{2}{|c|}{ Group } & Beam & Translational type-axial \\
\hline \multirow{2}{*}{ 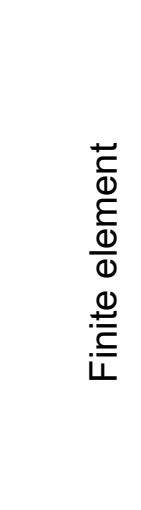 } & 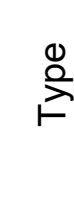 & $\begin{array}{l}\text { Beam } \\
\text { elements }\end{array}$ & $\begin{array}{l}\text { Connector elements } \\
\text { such as springs } \\
\text { and dashpots }\end{array}$ \\
\hline & $\begin{array}{l}\frac{0}{d} \\
\frac{1}{0} \\
\frac{0}{0} \\
0\end{array}$ & end 2 & \\
\hline
\end{tabular}

\subsection{Modeling of mechanical dampers}

Mechanical dampers are modeled by link elements with ultimate forces and ultimate displacements with the assumption that the entire diagonal is a single element, although in reality a mechanical damper is installed on an additional element because it is relatively small in size. The mechanical properties of dampers depend on the damper manufacturer's specifications. Type "Multi-Linear Elastic" axial links were used for modeling in SAP2000, while in ABAQUS they were modeled by "Connector" elements. The selected element type is "translational basic axial elements", which allows connection and movement in the direction of the line connecting the given points. Figure 11 right shows the behavior of the mechanical damper. 

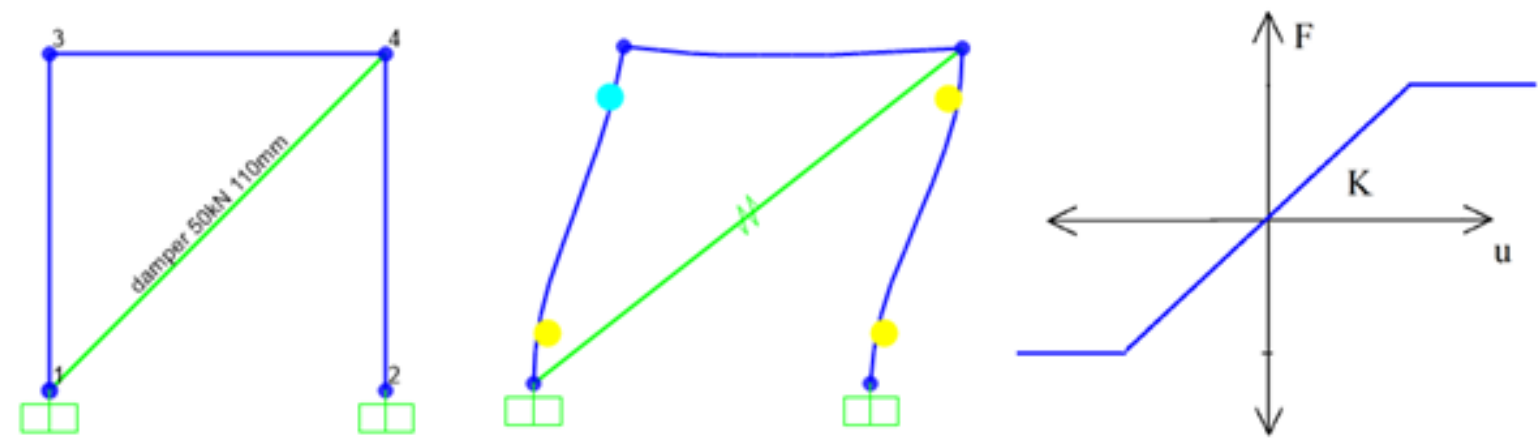

Figure 11. Numerical model of the metal frame reinforced with mechanical dampers, location of formation of plastic hinges in SAP2000 and behavior of a mechanical damper

In further text, hysteretic metal dampers will be used and marked as MD" $\mathrm{X}$ "kN"Y"mm, where: " $X$ " is the ultimate bearing capacity of the damper in [kN] and " $Y$ " is the ultimate displacement in $[\mathrm{mm}]$, which are defined by the mechanical damper manufacturer's specifications.

\section{PUSHOVER ANALYSIS OF METAL FRAME}

After numerical models of metal frame were formed, pushover analysis was performed. The capacity curve obtained by nonlinear static pushover analysis is shown in Figure 12, while the resistance of the metal frame to transverse forces is $H_{\max } \approx 18.00 \mathrm{kN}$.

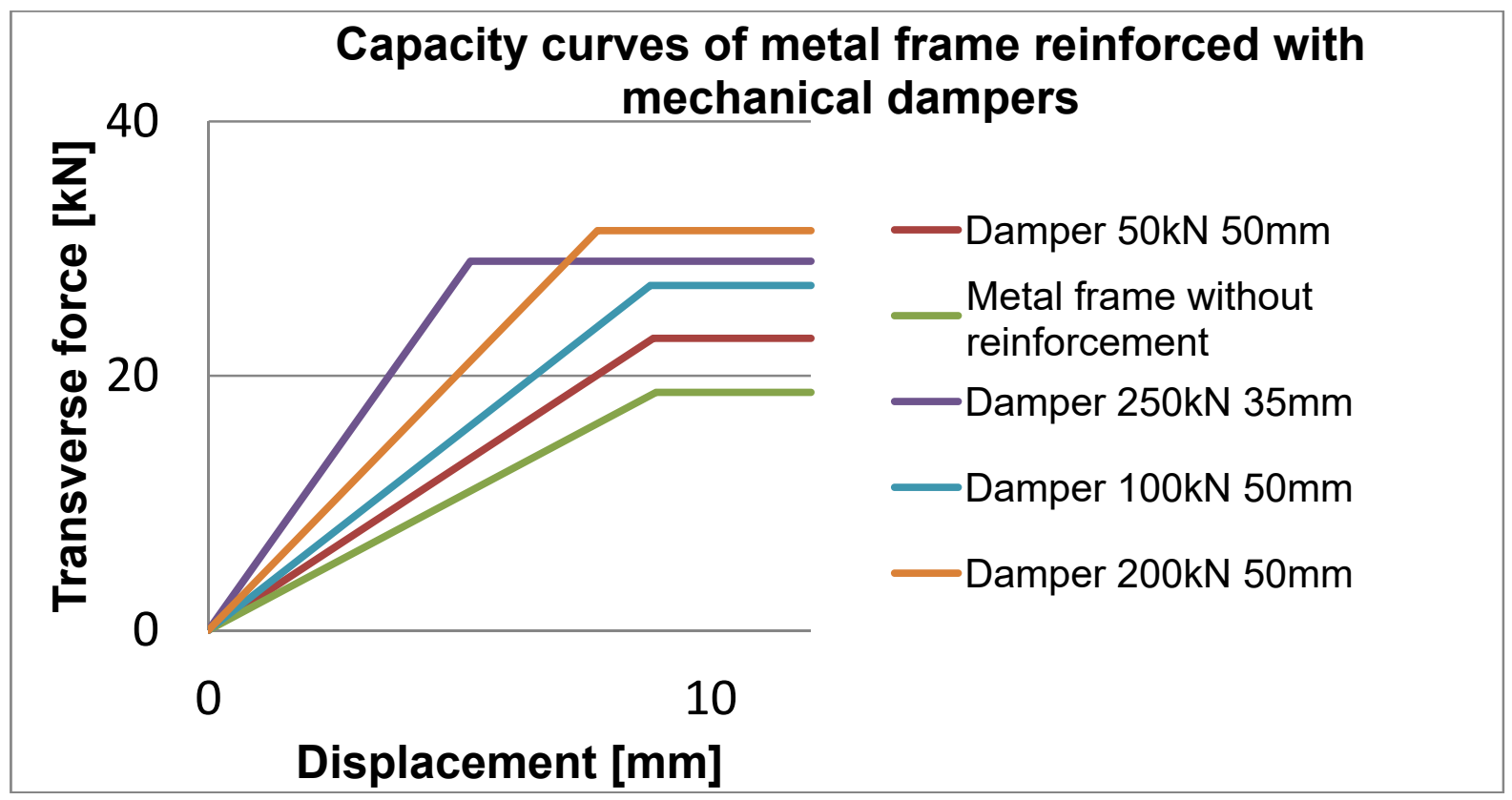

Figure 12. Capacity curves of metal frame with and without strengthening using mechanical dampers 
Buljubašić, E., Simonović, G.

Analysis of steel frames strenghtened with diagonally installed mechanical dampers

\section{PUSHOVER ANALYSIS OF METAL FRAME STRENGTHENED WITH MECHANICAL DAMPERS}

A diagonal modeled with link (SAP2000) or connector (ABAQUS) elements, which will simulate the behavior of a mechanical damper, was added to the previously analyzed metal frame. Mechanical dampers of different specifications, or different ultimate values of displacement and bearing capacity, were used. The effects of the mechanical damper are multiple, stiffening of the metal frame increases the resistance to transverse forces and decreases the displacement of the top of the frame due to lateral actions. The obtained capacity curves of metal frame with and without strengthening are shown in Figure 12.

\section{DYNAMIC TESTING OF METAL FRAME STRENGTHENED WITH MECHANICAL DAMPERS}

The metal frame without reinforcement was subjected to cyclic loading with a displacement program that has three cycles of four repetitions each, shown in Figure 13. After reaching the ultimate displacement, at a force of $\mathrm{H}_{\max } \approx 8.00 \mathrm{kN}$ the metal frame begins to flow, which can be clearly seen in Figure 13. The metal frame reinforced with mechanical damper "MD50kN50mm" was subjected to the same conditions and the positive effects of its use are evident through an increase in stiffness of the system and increase in resistance of the system to transverse forces (Figure 14).

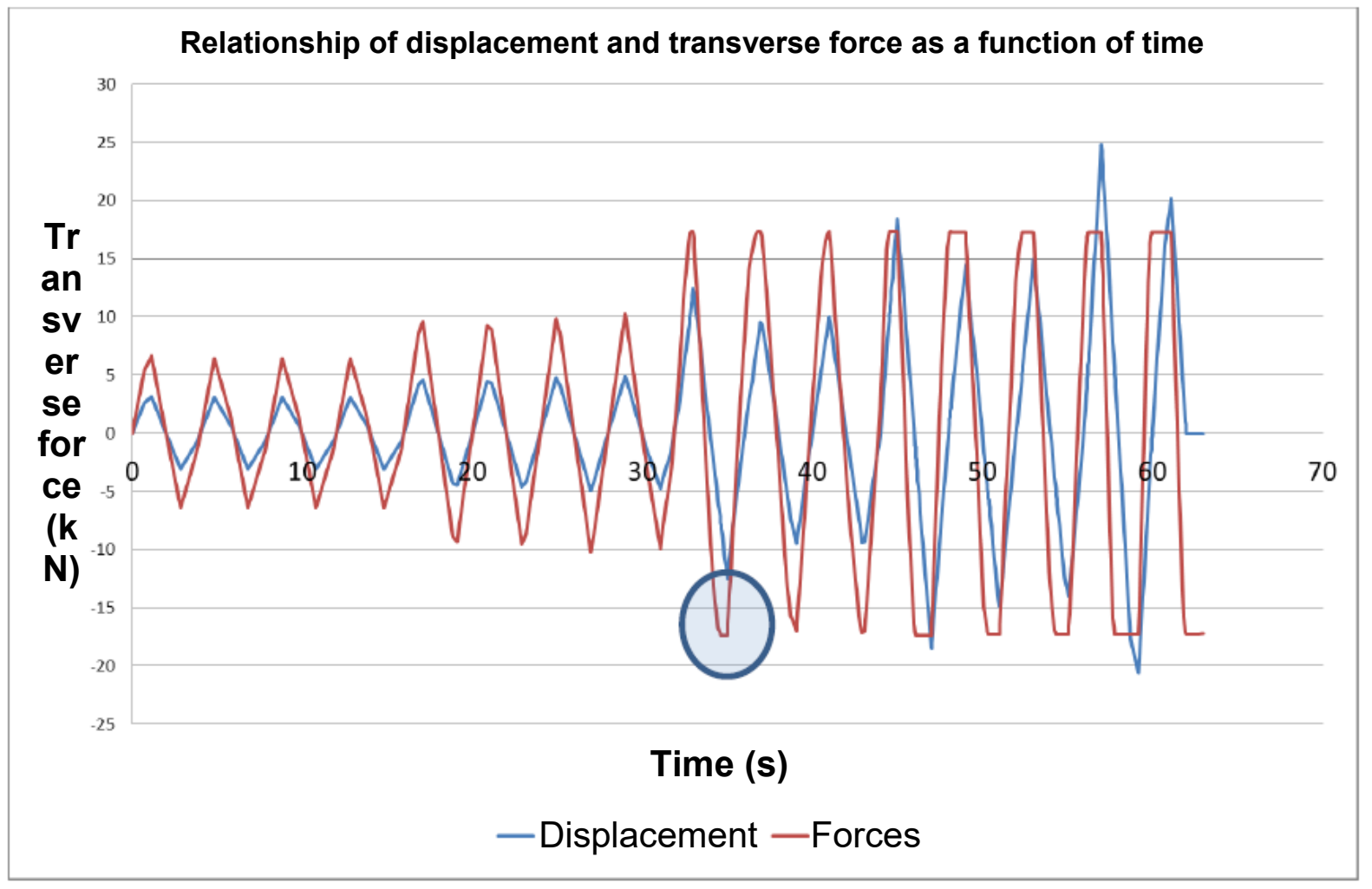

Figure 13. Transverse force and displacement of the metal frame without reinforcement as a function of time 
Buljubašić, E., Simonović, G.

Analysis of steel frames strenghtened with diagonally installed mechanical dampers

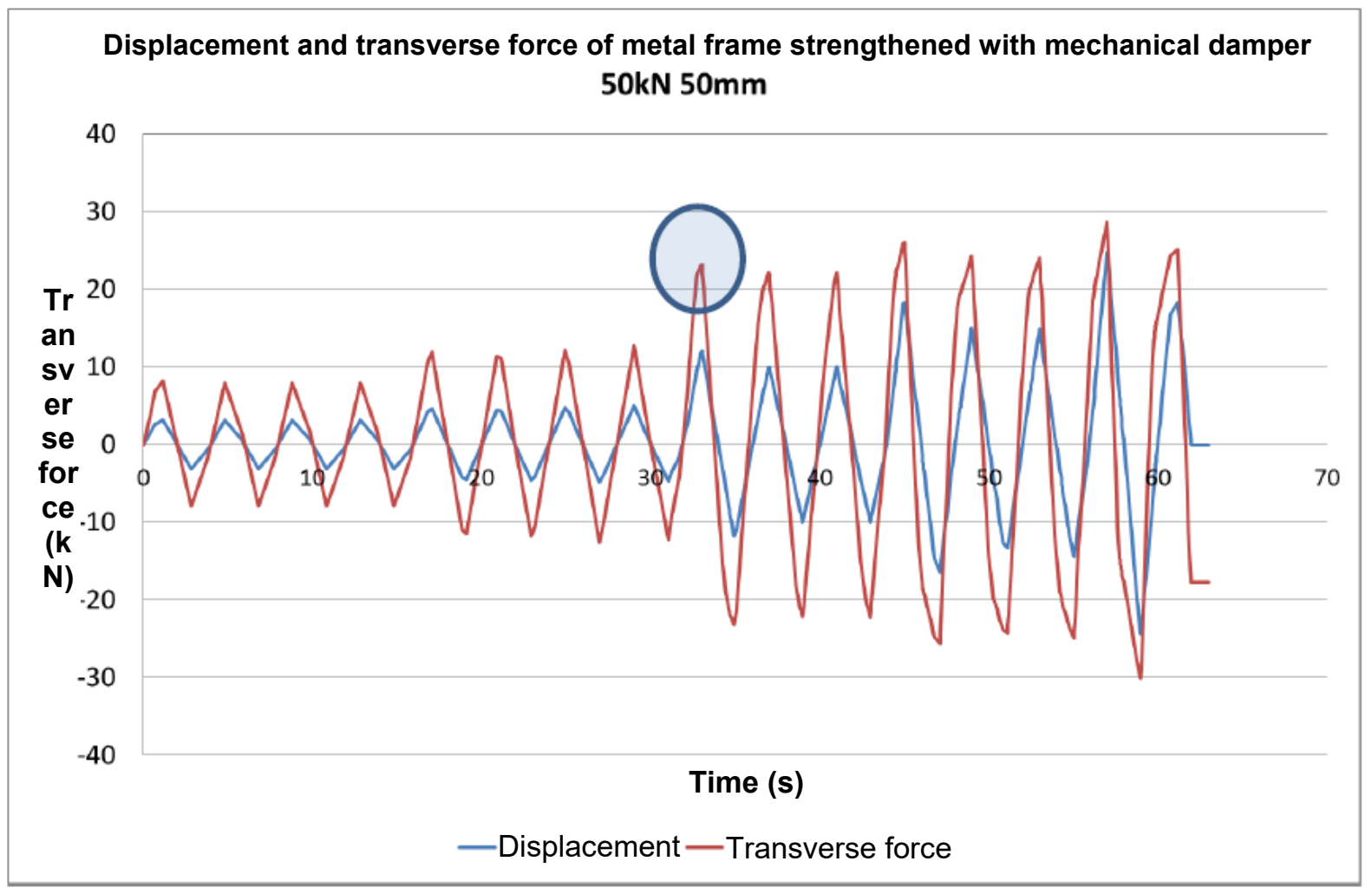

Figure 14. Transverse force and displacement of the metal frame reinforced with mechanical damper MD $50 \mathrm{kN} 50 \mathrm{~mm}$ as a function of time

It is important to note that the behavior of the entire system, in this case the metal frame strengthened with mechanical dampers, depends on the behavior of the individual components of the frame and the mechanical damper. The behavior of the strengthened system should be approximately equal to the sum of nonlinear responses of the metal frame and the damper at the same displacement (Figure 15), [11].
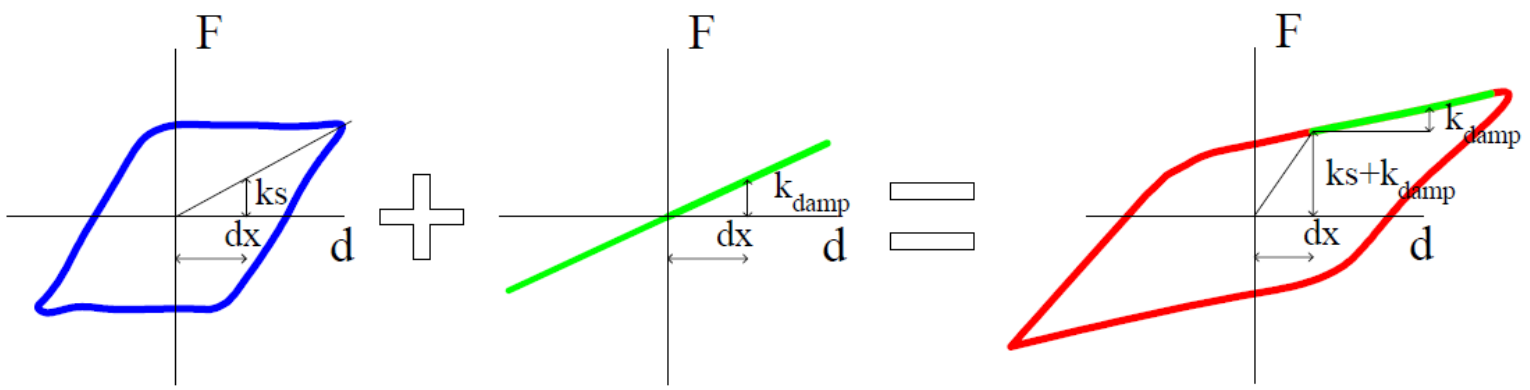

Figure 15. Behavior of the system is shown as the sum of the transverse force and displacement at the top of the frame 
Buljubašić, E., Simonović, G.

Analysis of steel frames strenghtened with diagonally installed mechanical dampers

The stiffness of the strengthened system, $k_{0}$, should be equal to the sum of the stiffness of the metal frame, $k_{s}$, and of the mechanical damper $k_{\text {damp }}$ for the same displacement value $\mathrm{dx}$ (Figure 15). As an additional control of the given statement, the metal frame was tested with and without reinforcement and the effects of reinforcement were compared. Figure 16 shows the hysteresis curve of the unreinforced metal frame. It is clearly evident that the backbone curve corresponds to the capacity curve obtained in the previous chapter.

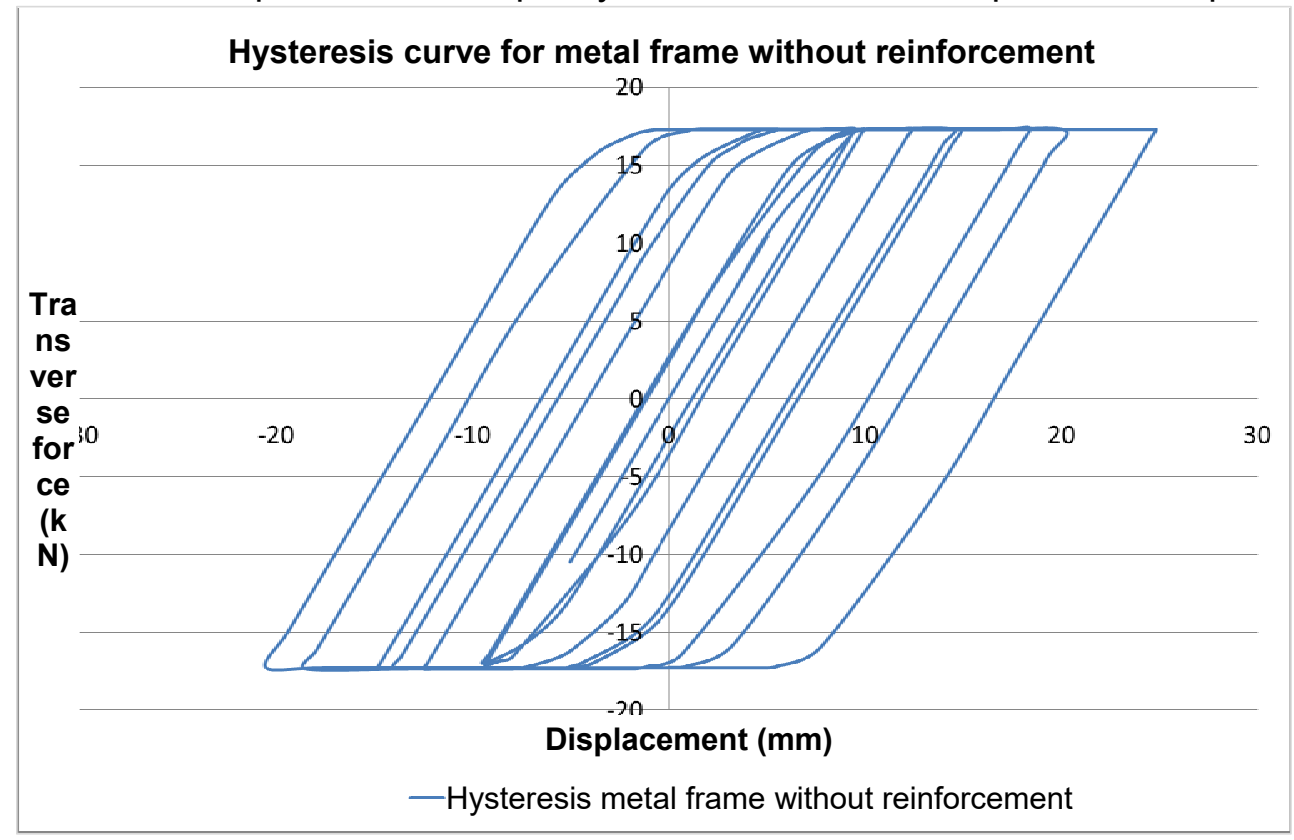

Figure 16. Hysteresis curve for metal frame without reinforcement

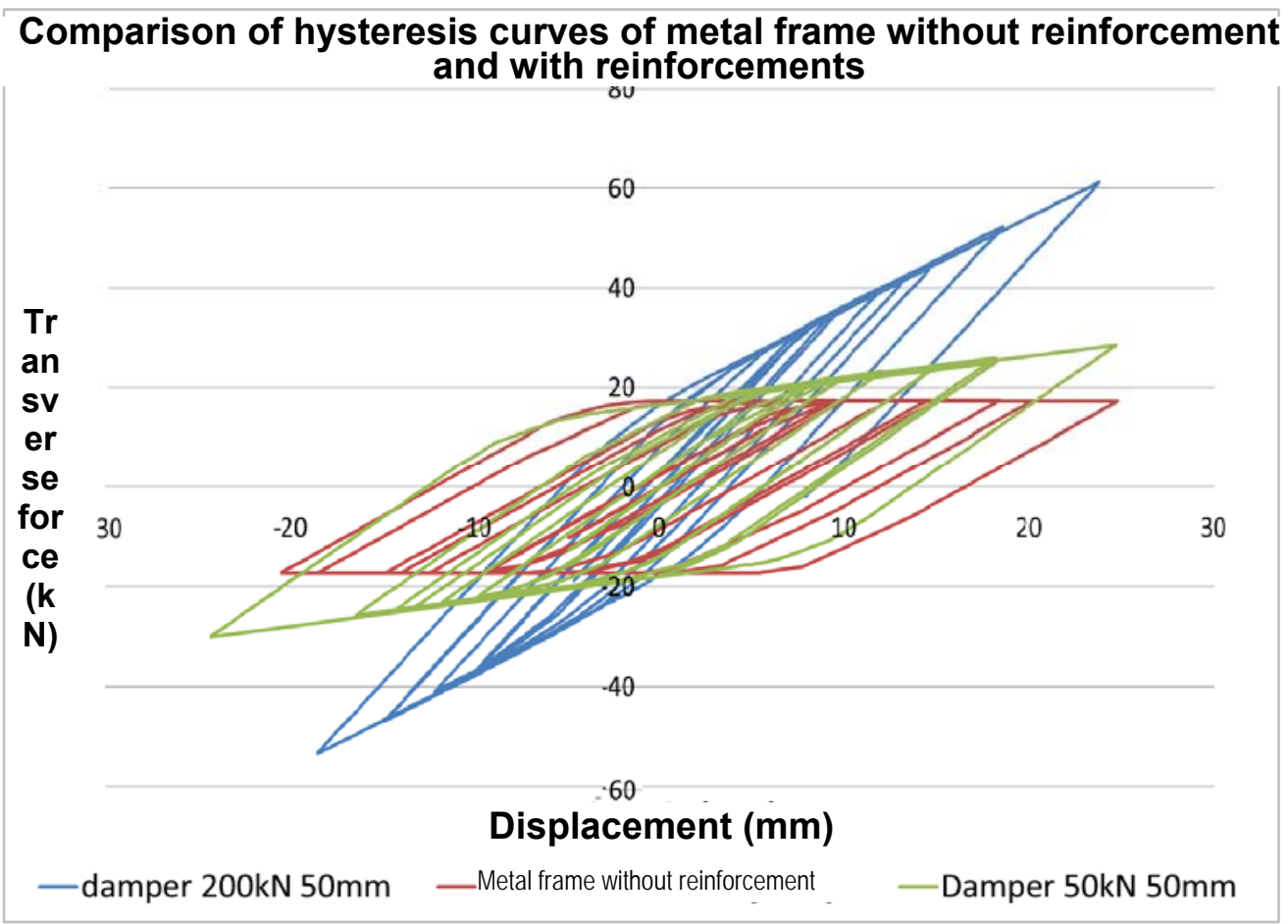

Figure 17. Comparison of hysteresis curves of metal frames with and without reinforcement 
Buljubašić, E., Simonović, G.

Analysis of steel frames strenghtened with diagonally installed mechanical dampers

The metal frame was reinforced using mechanical dampers "MD50kN50mm" and "MD200kN50mm" and the obtained hysteresis curves were compared with the unreinforced frame (Figure 17). A comparison of the hysteresis curves shows that, for a given displacement, the stiffness of the reinforced system (Figure 18) at a given point is equal to the sum of the stiffnesses of the metal frame and of the mechanical damper.

\section{RECAPITULATION}

There are different types of reinforcement of masonry walls, and one of them is the use of metal frames. Since masonry walls are highly vulnerable to seismic effects, the idea is to transfer this effect to another element, in this case the metal frame. The metal frame is placed directly near the wall so that it can participate in taking the load. The function of such frames is to take the transverse forces resulting from seismic actions as well as to take the bending moments of the masonry wall by resolving them into a force couple that will be taken by metal frame columns (Figure 18).

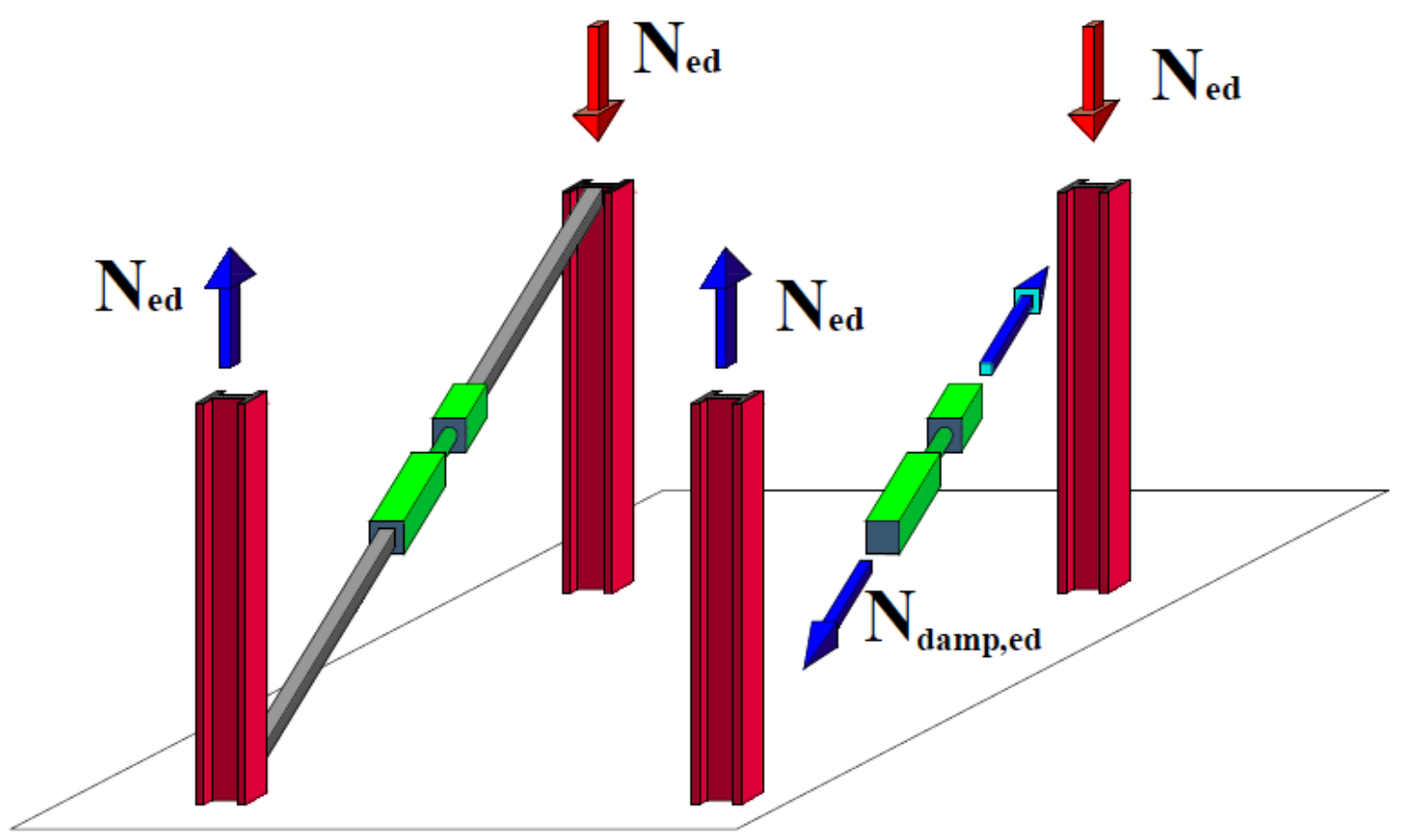

Figure 18. Metal frame strengthened with mechanical dampers and force transfer plan

A metal frame with and without reinforcement was analyzed using mechanical dampers of different specifications. The results of numerical analyses are shown in Table 2. 
Buljubašić, E., Simonović, G.

Analysis of steel frames strenghtened with diagonally installed mechanical dampers

Table 2. Overview of analysis results of metal frames with and without strengthening

\begin{tabular}{|c|c|c|c|c|c|c|}
\hline \multirow{4}{*}{$\begin{array}{l}\frac{\infty}{\tilde{D}} \\
\stackrel{E}{\Phi} \\
\frac{\Phi}{W}\end{array}$} & \multicolumn{3}{|c|}{ Mechanical damper } & \multirow{2}{*}{\multicolumn{2}{|c|}{$\begin{array}{l}\text { Ultimate values at failure of } \\
\text { the element }\end{array}$}} & \multirow{3}{*}{$\begin{array}{l}\text { Percentage } \\
\text { increase in } \\
\text { transverse } \\
\text { bearing } \\
\text { capacity upon } \\
\text { reinforcement }\end{array}$} \\
\hline & \multirow{3}{*}{$\begin{array}{l}\text { Name } \\
\text { (MD) }\end{array}$} & \multicolumn{2}{|c|}{ Specifications } & & & \\
\hline & & $\begin{array}{l}\text { Ultimate } \\
\text { force }\end{array}$ & $\begin{array}{c}\text { Ultimate } \\
\text { displacement }\end{array}$ & $\begin{array}{l}\text { Transverse } \\
\text { force }\end{array}$ & Displacement & \\
\hline & & {$[\mathrm{kN}]$} & {$[\mathrm{mm}]$} & {$[\mathrm{kN}]$} & {$[\mathrm{mm}]$} & [\% ] \\
\hline \multicolumn{2}{|c|}{ Metal frame } & - & - & 18.71 & 8.92 & - \\
\hline \multirow{4}{*}{ 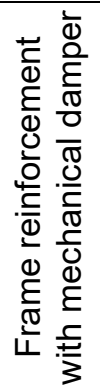 } & $50 \mathrm{kN} 50 \mathrm{~mm}$ & 50 & 50 & 22.96 & 8.86 & 22.71 \\
\hline & $100 \mathrm{kN} 50 \mathrm{~mm}$ & 100 & 50 & 27.11 & 8.80 & 44.90 \\
\hline & $200 \mathrm{kN} 50 \mathrm{~mm}$ & 200 & 50 & 31.42 & 7.75 & 67.93 \\
\hline & $250 \mathrm{kN} 35 \mathrm{~mm}$ & 250 & 35 & 29.01 & 5.22 & 55.05 \\
\hline
\end{tabular}

It can easily be seen that the application of mechanical dampers increases the stiffness of the system. With the use of higher-stiffness mechanical dampers, the transverse resistance of the global system increases and the system displacements decrease (Figure 19 and Figure 20).

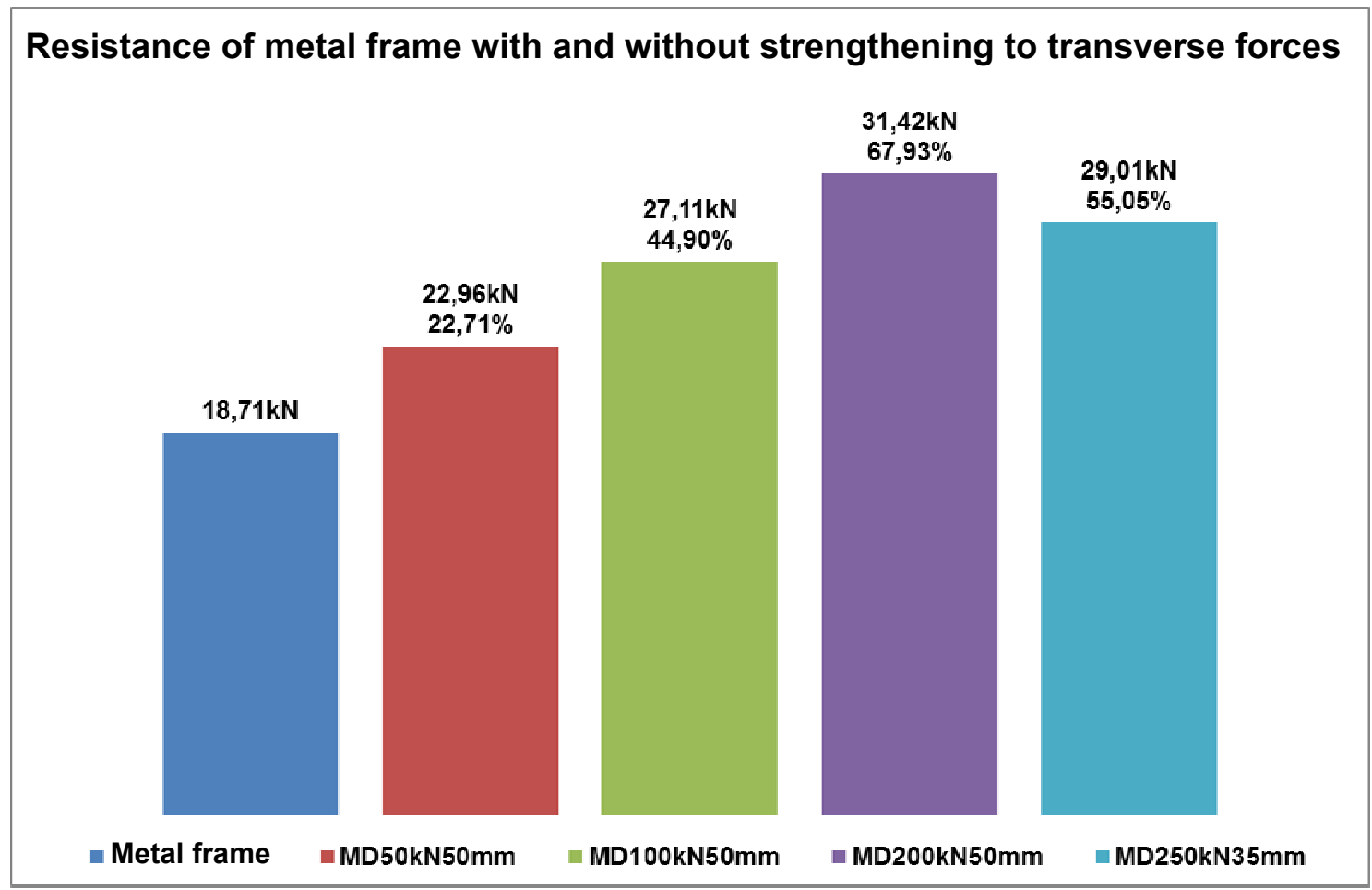

Figure 19. Resistance of metal frame with and without strengthening to transverse forces 
Buljubašić, E., Simonović, G.

Analysis of steel frames strenghtened with diagonally installed mechanical dampers

Particular attention must be paid when dimensioning the frame columns since the use of mechanical dampers of higher stiffness will increase the axial force in the reinforced diagonal, which can cause stress concentration in column bases and ultimately lead to failure due to plasticization of the bases. Displacements of the system will be reduced almost by half (Figure 20), but when the column base plasticization occurs, the entire system will fail. The negative effect of combining dampers of high stiffness and frames of low resistance to transverse forces can be avoided by proper dimensioning.

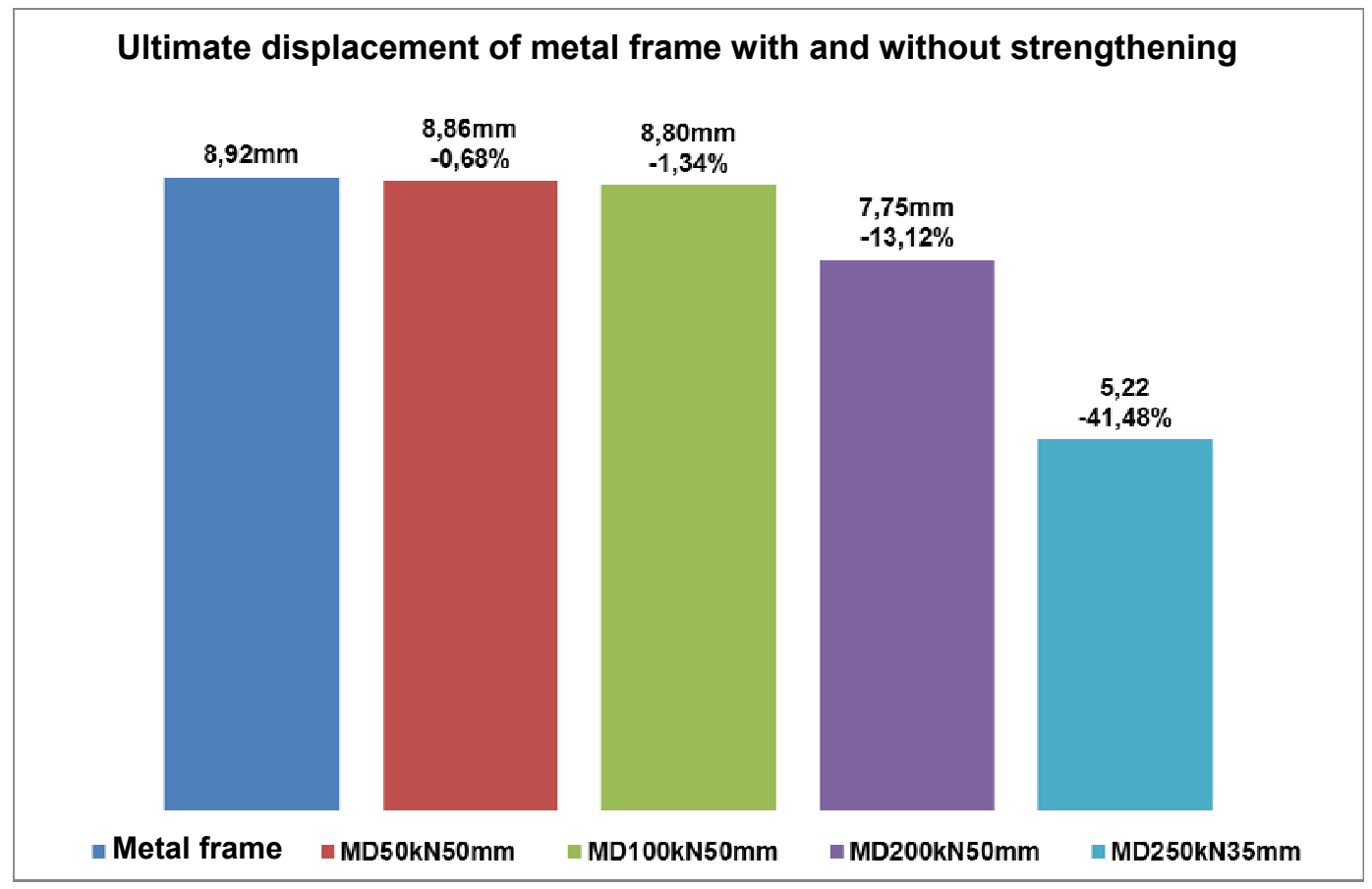

Figure 20. Ultimate displacements of metal frame with and without strengthening

\section{CONCLUSION}

The presented paper shows an analysis of metal frame strengthening using diagonally installed mechanical dampers, where the focus of the paper is placed on the effect of increasing the system stiffness by using mechanical dampers.

It should be noted that the dimensions of frame elements primarily depend on the geometry and precompression levels of the existing masonry walls that need to be strengthened, which will be discussed in more detail in future papers.

Numerical analysis confirmed that the stiffness of the strengthened system, $\mathrm{k}_{0}$, is equal to the sum of the stiffnesses of the metal frame, $k_{s}$, and of the mechanical damper $k_{\text {damp }}$ for the same displacement value $\mathrm{dx}$.

In addition to increasing the system stiffness, the diagonal reinforcement also reduces the frame bending lengths, i.e. it leads to a decrease in displacement and an increase in resistance to transverse forces. With the use of higher-stiffness mechanical dampers, the global system resistance to transverse forces increases proportionally. It is also very important to pay attention to proper dimensioning of metal frame columns taking into account the relationships between the stiffnesses of mechanical dampers and columns. If the diagonals have higher stiffness than the frame columns, concentration of stresses will occur in frame corners, which will cause the column bases to plasticize and the system to fail. 
Buljubašić, E., Simonović, G.

Analysis of steel frames strenghtened with diagonally installed mechanical dampers

\section{REFERENCES}

1. Buljubašić, E., Simonović, G.: Analysis of masonry walls strengthened with mechanical dampers, e-Zbornik: Electronic Collection of Papers of the Faculty of Civil Engineering, Vol. 9, No. 18, 2019.

2. Hrasnica, M., Biberkić, F., Medić, S.: In-Plane Behavior of Plain and Strengthened Solid Brick Masonry Walls, Key Engineering Materials, July 2017.

3. Hrasnica, M., Medić, S., Ademović, N.: Cyclic shear tests on URM and strengthened masonry walls and its modelling, Conference Paper, Second European Conference on Earthquake Engineering and Seismology, August 2014.

4. Hrasnica, M., Medić, S., Biberkić, F.: Experimental Testing of Solid Brick Masonry Walls, 16th European Conference on Earthquake Engineering, June 2018.

5. Hrasnica, M., Medić, S.: Finite element modeling of experimentally tested solid brick masonry walls, 16th European Conference on Earthquake Engineering, June 2018.

6. Medić, S.: Eksperimentalna i numerička analiza zidova od pune opeke izloženih utjecaju potresa (Experimental and numerical analysis of solid brick walls subjected to earthquake effects), Doctoral Thesis, Faculty of Civil Engineering University of Sarajevo, 2018.

7. Sučević, P.: Protupotresna izolacija građevina (Earthquake-resistant isolation of structures), Master's Thesis, Faculty of Civil Engineering Zagreb, unknown year of publication

8. Castaldo, P.: Integrated Seismic Design of Structure and Control Systems, Springer Tracts in Mechanical Engineering, Springer International Publishing Switzerland, 2014

9. Liang, Z., Lee, G.C., Dargush, G.F., Song, J.: Structural damping: Applications in Seismic Response Modification, CRC Press Taylor \& Francis Group, 2012.

10. Simonović, V., Simonović, G.: Nelinearna statička analiza po preporukama FEME 273, $274,356,440$ i 450 i njena praktična primjena uz pomoć kompjuterskog software-a sap2000, Materijali i konstrukcije 50, No.1-2, 2007.

11. Simonović, V., Šahinagic-Isović, M., Selimotić, M., Simonović, G.: Numerical analysis of seismic resistance of masonry buildings using passive dampers, 16th European Conference on Earthquake Engineering, June 2018.

12. Sap2000, CSI Analysis Reference Manual, Computers and Structures, Inc., Berkley, California, USA, 2003. 